\title{
ОТРУЄННЯ БЛІДОЮ ПОГАНКОЮ: МЕХАНІЗМ ТОКСИЧНОСТІ ТА ПАТОГЕНЕЗ УРАЖЕННЯ (ОГЛЯД ЛІТЕРАТУРИ)
}

Вступ. Бліда поганка (Amanita phalloides) є одним із найнебезпечніших отруйних грибів. Iї токсини належать до сильних отрут, які проявляють гепатонефротропну дію, а з огляду на відсутність специфрічних антидотів до них, лікування отруєнь цим грибом залишається важливою проблемою. Токсини блідої поганки поділяють на три групи: фралотоксини, що уражають ендоплазматичну сітку, аматоксини, які діють повільніше, але майже у 20 разів отруйніші, ніж перші, та віротоксини. Аматоксини є основними токсинами Amanita phalloides та одними з найнебезпечніших природних токсинів, що викликають печінкову, ниркову, в цілому поліорганну, недостатність унаслідок пригнічення синтезу білка на рівні транскрипції всередині ентероцитів, гепатоцитів і проксимальних канальцевих клітин нирок. Після споживання Amanita phalloides аматоксини часто індукують масивний некроз клітин печінки з високим рівнем смертності, який сягає іноді $90 \%$.

Суттєвого значення в патогенезі аманіта-фралоїдинового ушкодження надають порушенню обміну білків унаслідок пригнічення РНК-полімерази II клітин, прямій інгібуючій дії на активність уже синтезованих ензимів та непрямому впливу на ензимні системи через субстрати.

Іншим механізмом токсичності $\alpha$-аманітину є утворення активних фрорм кисню, що призводить до ушкодження, пов'язаного з окиснювальним стресом. Пероксидне окиснення ліпідів може сприяти виникненню масивного некрозу і тяжкої гепатотоксичності.

У цій роботі наведено детальний огляд літератури щодо отруєння основними токсинами блідої поганки. У статті обговорюються питання стосовно біохімії аматоксинів, фралотоксинів та інших токсинів блідої поганки, механізмів токсичності, патогенезу отруєння цим грибом.

У даній роботі використано загальнонаукові методи дослідження, що включають експертно-аналітичний огляд наукових джерел, аналіз і синтез літературних даних.

Мета дослідження - проаналізувати сучасні літературні джерела про біохімію токсинів блідої поганки, механізми токсичності, патогенез отруєння цим грибом.

Висновок. Аналіз літературних джерел об'рунтовує актуальність дослідження механізмів токсичності та патогенезу ураження токсинами блідої поганки з метою виявлення метаболічних порушень, що необхідно для прогнозування тяжкості перебігу патологічного процесу, пошуку і розробки методів лікування аматоксин-фралоїдинових отруєнь.

КЛЮЧОВІ СЛОВА: бліда поганка; отруєння грибами; гепатотоксичність; аматоксини; фралотоксини.

Гриби становлять частину раціону людини завдяки їх вишуканому смаку та вмісту білка, їх традиційно використовують у всьому світі як поживну їжу і лікарські джерела, що мають антиоксидантну активність [1].

Гриби мають велику харчову цінність, оскільки є багатими джерелами вуглеводів, білків, вільних амінокислот і вітамінів, а також різних важливих мінералів та мікроелементів. Вони також багаті на біоактивні метаболіти з високою лікарською цінністю, такі, як лектини, полісахариди, фенольні та поліфенольні речовини, терпеноїди, ергостерини і леткі органічні сполуки. с) І. П. Кузьмак, 2020.
Таким чином, екстракти грибів використовували в медицині як імуномодулятори, протипухлинні, антибактеріальні та противірусні засоби, антиоксиданти тощо [2-4].

Токсичні та нетоксичні гриби часто мають значну морфологічну схожість, що вводить в оману збирачів (споживачів) і спричиняє мікотоксичність. Численні види грибів вважають "отруйними", оскільки вони виробляють небезпечні токсини. Наприклад, представники роду Amanita, особливо A. phalloides, A. virosa та A. verna, відповідальні за тяжкій навіть небезпечні для життя шкідливі наслідки. У всьому світі отруєння грибами $є$ найважливішим питанням 
охорони здоров'я, оскільки щороку призводить до значної кількості смертей. Однак жодного антидоту для лікування цього отруєння не знайдено [2].

На теренах України кількість постраждалих 3 діагнозом "Отруєння грибами” коливається від 700-800 до 1500-2500 випадків на рік [5].

Отруєння грибами є глобальною проблемою і викликає велику смертність та захворюваність. 3 понад 2000 визначених у всьому світі видів грибів лише близько 50 токсичні для людини [6]. Належачи до цих 50 видів, Amanita phalloides відповідає за більшість смертей, спричинених отруєнням грибами [7]. Отруєння аматоксинами зазвичай має поганий прогноз через високий ризик виникнення печінкової недостатності. У світі не існує загальновизнаних вказівок щодо лікування отруєння аматоксинами [8].

3 наведеної інфрормації зрозуміло, що отруєння токсинами блідої поганки - проблема в усьому світі. Тому цей огляд має на меті ширше представити наявну на даний час інформацію про механізми токсичності, закономірності клінічного перебігу внаслідок отруєння токсинами Amanita phalloides.

Отрута блідої поганки містить "цілий букет" сильнодіючих токсинів, які вчені поділили на три великі групи: фралотоксини, аматоксини, віротоксини. Вони являють собою поліциклічні пептиди. Крім них, виявляють ще один токсин антаманід. Кожен із цих токсинів має свою мету ураження, а в комплексі вони, срактично, цілковито порушують обмін речовин в організмі.

Усі групи токсинів містять залишок триптофану, заміщений у положенні 2 кільця індолу атомом сірки (рис. 1-3).

Фалотоксини - це щонайменше сім сполук, усі з яких є біциклічними гептапептидами. Аматоксини - це принаймні дев'ять споріднених токсичних сполук з восьми амінокислотних залишків, розташованих у збереженій пентацикліч- ній структурі. Віротоксини - це моноциклічні пептиди, представлені щонайменше п'ятьма різними сполуками. Їх структура та біологічна активність подібні до таких у фралотоксинів, це дозволяє припустити, що вони мають спільні шляхи попередника [2, 8].

Однією з медичних проблем при отруєннях мухомором фралоїдним $€$ відносно тривалий латентний період (8-24 год) від споживання грибів, одночасно проявляється цитотропна дія поглинених токсинів, які надходять із кров'ю до печінки, внаслідок чого відбуваються збільшення їі розміру та відтік іонів калію і лізосомних ензимів з наступним руйнуванням клітин [9].

У тяжких випадках можуть виникнути поліорганна недостатність, ниркова та гепатитна недостатність. Смерть у випадках, спричинених аманітином, настає через 6-16 днів після інтоксикації. Смертність у цієї групи пацієнтів усе ще висока і становить приблизно 20-30 \% у дорослих та перевищує 50 \% у дітей [10].

Токсичність раннього початку зазвичай включає нейротоксичний, шлунково-кишковий та алергічний синдроми, токсичність, що виникає пізно, - гепатотоксичний і нефротоксичний синдроми, а токсичність з уповільненим початком нефротоксичний та нейротоксичний синдроми [11].

Фалотоксини - це біциклічні гептапептиди, вперше виділені з Amanita phalloides [12] і представлені принаймні сімома різними сполуками: фралоїдином, фралоїном, профралоїном, фралізином, фралацином, фралацидином та фралісацином (рис. 1) [13].

Усі фралотоксини мають подібні склад і будову, але існують відмінності в бічних ланцюгах. Ці бічні ланцюги є дериватом лейцину, який у у-положенні містить гідроксильну групу (OH). Структуру деяких фралотоксинів наведено на рисунку 1, а бічних ланцюгів таких речовин - у таблиці 1.

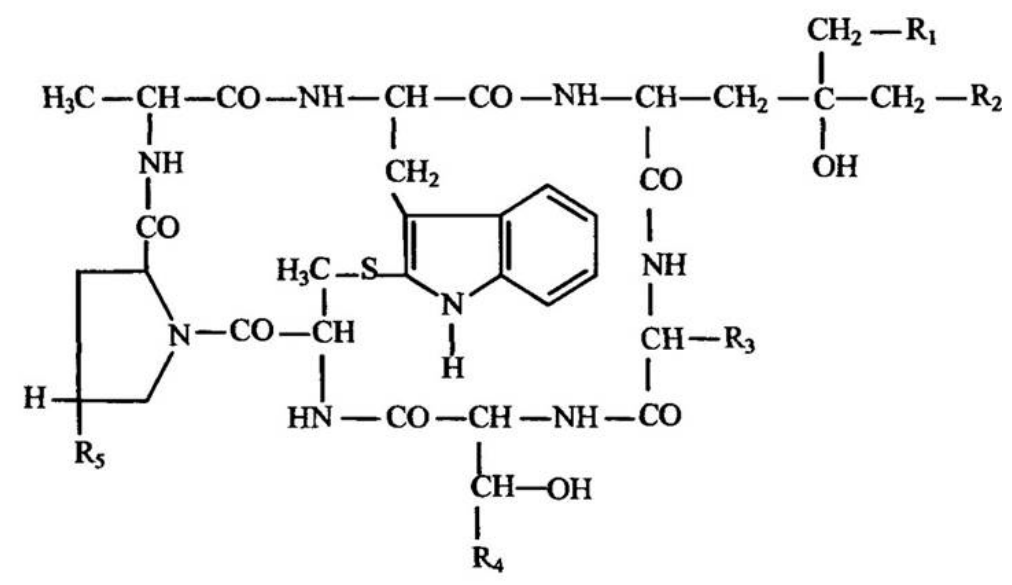

Рис. 1. Хімічна структура фралотоксинів. 
Таблиця 1 - Структура бічних ланцюгів фралотоксинів

\begin{tabular}{||l|c|c|c|c|c||}
\hline \multirow{2}{*}{$\begin{array}{c}\text { Назва } \\
\text { фалотоксину }\end{array}$} & \multicolumn{5}{|c||}{ Структра бічних ланцюгів } \\
\cline { 2 - 6 } & $\mathrm{R}_{1}$ & $\mathrm{R}_{2}$ & $\mathrm{R}_{3}$ & $\mathrm{R}_{4}$ & $\mathrm{CH}_{5}$ \\
\hline Фалоїдин & $\mathrm{OH}$ & $\mathrm{H}$ & $\mathrm{CH}_{3}$ & $\mathrm{CH}_{3}$ & $\mathrm{OH}$ \\
\hline Фалоїн & $\mathrm{H}$ & $\mathrm{H}$ & $\mathrm{CH}_{3}$ & $\mathrm{CH}_{3}$ & $\mathrm{OH}$ \\
\hline Профралоїн & $\mathrm{OH}$ & $\mathrm{H}$ & $\mathrm{CH}_{3}$ & $\mathrm{CH}_{3}$ & $\mathrm{H}$ \\
\hline Фалізин & $\mathrm{OH}$ & $\mathrm{OH}$ & $\mathrm{CH}_{3}$ & $\mathrm{CH}_{3}$ & $\mathrm{OH}$ \\
\hline Фалацин & $\mathrm{H}$ & $\mathrm{H}$ & $\mathrm{CH}_{2}\left(\mathrm{CH}_{3}\right)_{2}$ & $\mathrm{COOH}$ & $\mathrm{OH}$ \\
\hline Фалацидин & $\mathrm{OH}$ & $\mathrm{H}$ & $\mathrm{CH}\left(\mathrm{CH}_{3}\right)_{2}$ & $\mathrm{COOH}$ & $\mathrm{OH}$ \\
\hline Фалісацин & $\mathrm{OH}$ & $\mathrm{OH}$ & $\mathrm{CH}\left(\mathrm{CH}_{3}\right)_{2}$ & $\mathrm{COOH}$ & $\mathrm{OH}$ \\
\hline \hline
\end{tabular}

Фалоїдин (молекулярна маса 900 Да) вперше ідентифікував у 1937 р. T. Wieland [12]. 3агальна амінокислотна послідовність: Ala1 Trp2 - Leu3 - Ala4 - Thr5 - Cys6 - Pro7. 3 них фралоїдин, фралоїн, профралоїн і фралізин класифрікують як нейтральні фралотоксини, тоді як фалацин, фралацидин та фралісацин - це кислі сралотоксини. Фалотоксини не всмоктуються шлунково-кишковим трактом.

Одні з проявів дії фралотоксинів - порушення структурних перебудов мікрофріламентів гепатоцитів, пригнічення процесів їх транслокації в клітинах. Це пов'язано з тим, що фалотоксини при зв'язуванні з актином або актиноподібними білками викликають їх полімеризацію. Вони міцно зв'язуються з F-актином, який стабілізує актинові нитки та запобігає деполімеризації мікрофріламентів, порушуючи правильну фрункцію цитоскелета [2, 13, 14].

Разом із тим, фалотоксини проявляють незначну гемолітичну дію - здатні руйнувати червоні кров'яні тільця, що обмежує доступ кисню до тканин і органів.

Токсична дія фралотоксинів пов'язана з їх впливом на мембрану та органели гепатоцитів спричиняє зміни ліпідного складу плазматичних мембран гепатоцитів, зменшення вмісту холестеролу і збільшення концентрації фоосфоліпідів. У щурів після введення фралоїдину розвивається дистрофрія печінки, знижується або повністю припиняється секреція жовчі. Встановлено, що фралоїдин, крім зменшення синтезу білка гепатоцитами, пригнічує також синтез глікогену. Одночасно з дією на гепатоцити фралотоксини порушують цілісність епітелію та судин кишечника. Проникаючи всередину клітини, вони спричиняють деструкцію внутрішньоклітинних органел, вихід із вакуолей протеаз і лізис клітини. Клінічно це реалізується токсичним гастроентеритом та гастроентероколітом. Фалотоксини ушкоджують мембрани мітохондрій, ендоплазматичного ретикулума, лізосом, порушуючи процеси окисного фооссрорилювання, викликають зниження активності АТФ-ази. Надходження в організм великої концентрації цих речовин зумовлює розвиток клініки отруєння на 1-2 добу 3 виникненням депресивних синдромів, ураження ЦНС, токсичної гепаторгії і швидкою смертю хворого. Але слід зазначити, що токсичність фралотоксинів у 10 разів менша порівняно з аматоксинами $[13,15]$.

У плодових тілах гриба виявлено також токсичні білки, зокрема фралолізин [16], що $€$ гемолітичним лектином, і нелектинові білки, яким теж притаманна токсичність стосовно живих клітин. Нелектинові білки, очевидно, відіграють значно меншу роль в отруєнні грибами, оскільки термолабільні й мають нижчу токсичність. Фалолізин - це один з небагатьох токсичних лектинів, які володіють як гемаглютинуючою, так і гемолітичною активністю $[9,17,18]$.

Аматоксини було ідентифіковано як біциклічні октапептиди з молекулярною масою близько 900 г/моль, вони представлені щонайменше дев'ятьма різними сполуками, такими, як: $\alpha$-аманітин, $\beta$-аманітин, у-аманітин, $\varepsilon$-аманітин, аманінамід, аманін, аманулін, аманулінова кислота і проаманулін (рис. 2) [13]. 3 них $\alpha$-аманітин, y-аманітин, аманінамід, аманулін та проаманулін класисрікують як нейтральні аматоксини, тоді як ß-аманітин, ع-аманітин, аманін і аманулінова кислота - це кислі аматоксини.

Смертельна доза перорально введеного $\alpha$-аманітину для людини становить 0,1 мг/кг [19].

Основні токсикологічні дослідження було зосереджено на $\alpha$-аманітині та $\beta$-аманітинових токсинах, тому остаточних висновків щодо потенційних відмінностей між нейтральними і кислими аматоксинами неможливо зробити.

Аматоксини мають між собою подібну структуру, містять індольне кільце в системі кілець із тіоловим містком, а бічні ланцюги становлять деривати ізолейцину. Структуру аматоксинів наведено на рисунку 2 , а бічних ланцюгів конкретних отрут - у таблиці 2.

Токсини блідої поганки термостабільні, тому не втрачають токсичності при термічній обробці, висушуванні та зберіганні. Висока термостійкість поєднується з розчинністю у воді, що робить токсини надзвичайно токсичними. Крім того, аматоксини стійкі до деградації ензимів та кислот, а тому при потраплянні всередину вони не 


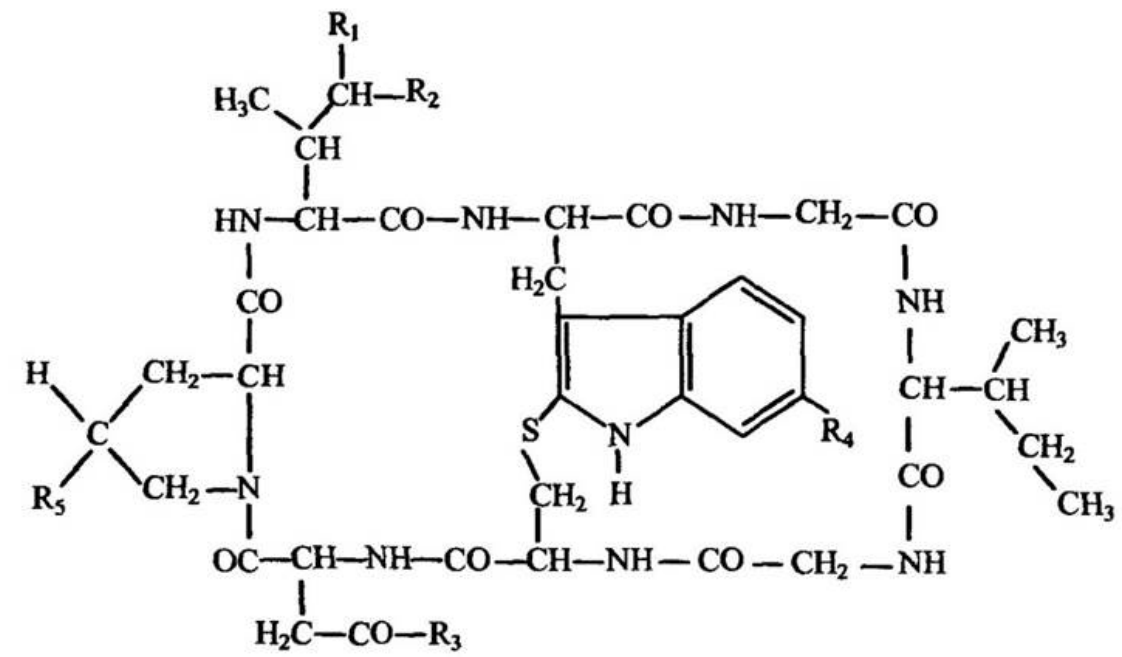

Рис. 2. Хімічна структура аматоксинів.

Таблиця 2 - Структура бічних ланцюгів аматоксинів

\begin{tabular}{||l|c|c|c|c|c||}
\hline \multirow{2}{*}{$\begin{array}{c}\text { амазва } \\
\text { аматокину }\end{array}$} & \multicolumn{5}{c|}{ Структура бічних ланцюгів } \\
\cline { 2 - 6 } & $\mathrm{R}_{1}$ & $\mathrm{R}_{2}$ & $\mathrm{R}_{3}$ & $\mathrm{R}_{4}$ & $\mathrm{R}_{5}$ \\
\hline$\alpha$-аманітин & $\mathrm{CH}_{2} \mathrm{OH}$ & $\mathrm{OH}$ & $\mathrm{NH}_{2}$ & $\mathrm{OH}$ & $\mathrm{OH}$ \\
\hline$\beta$-аманітин & $\mathrm{CH}_{2} \mathrm{OH}$ & $\mathrm{OH}$ & $\mathrm{OH}$ & $\mathrm{OH}$ & $\mathrm{OH}$ \\
\hline у-аманітин & $\mathrm{CH}_{3}$ & $\mathrm{OH}$ & $\mathrm{NH}_{2}$ & $\mathrm{OH}$ & $\mathrm{OH}$ \\
\hline$\varepsilon$-аманітин & $\mathrm{CH}_{3}$ & $\mathrm{OH}$ & $\mathrm{OH}$ & $\mathrm{OH}$ & $\mathrm{OH}$ \\
\hline Аманінамід & $\mathrm{CH}_{2} \mathrm{OH}$ & $\mathrm{OH}$ & $\mathrm{NH}_{2}$ & $\mathrm{H}$ & $\mathrm{OH}$ \\
\hline Аманін & $\mathrm{CH}_{2} \mathrm{OH}$ & $\mathrm{OH}$ & $\mathrm{OH}_{2}$ & $\mathrm{H}$ & $\mathrm{OH}$ \\
\hline Аманулін & $\mathrm{CH}_{3}$ & $\mathrm{H}$ & $\mathrm{NH}_{2}$ & $\mathrm{OH}$ & $\mathrm{OH}$ \\
\hline Проаманулін & $\mathrm{CH}_{3}$ & $\mathrm{H}$ & $\mathrm{NH}_{2}$ & $\mathrm{OH}$ & $\mathrm{H}$ \\
\hline
\end{tabular}

будуть інактивовані в шлунково-кишковому тракті $[8,12,13] . €$ повідомлення про смертельний випадок після споживання Amanita phalloides, яку заморожували протягом 7-8 місяців, це свідчить про те, що дані сполуки також протистоять процесам заморожування (розморожування) [20]. Крім того, аматоксини дуже повільно розкладаються при зберіганні у відкритих водних розчинах або після тривалого перебування на сонці чи неоновому світлі [8].

Першим органом-мішенню, який уражається токсинами блідої поганки, $є$ печінка, адже всі всмоктані травною системою речовини спершу проходять через цей своєрідний фрільтр організму. Порушення функцій печінки внаслідок загибелі їі клітин призводить до проникнення токсинів у кров, а з нею в усі органи. Відповідно, дані гепатоцелюлярні ефекти становлять найбільш смертельні та найменш ліковані прояви цієї токсичності [21].

Хоча фралотоксини та віротоксини діють швидше, аматоксини токсичніші в 10-20 разів і викликають переважно летальні випадки [22]. Аматоксини перш за все порушують діяльність клітин з високим ступенем білковосинтезувальної активності: гепатоцитів, судин ниркового епітелію, кардіоміоцитів тощо [5, 23].
Через шлунково-кишкове всмоктування аматоксинів печінка $€$ першим органом, який контактує з великою кількістю цих токсинів. Аматоксини накопичуються в печінці при поглинанні через органічні аніон-транспортувальні поліпептиди (ОАТР), що містяться в синусоїдальній мембрані гепатоцитів. K. Letschert та ін. ідентифрікували ОАТР ${ }_{1} B_{3}$ як головний транспортер поглинання людиною аматоксинів [24].

Аматоксинам приписують кілька механізмів токсичності. Основним механізмом, як відомо, $€$ їх здатність нековалентно зв'язувати й інгібувати в ядрі активність РНК-полімерази II, життєво важливого ензиму в синтезі мРНК, і малих ядерних РНК [12]. Зниження рівня МРНК призводить до зменшення синтезу білка і, зрештою, до загибелі клітин [2, 8, 12, 24]. При цьому транскрипція мРНК на ДНК повністю блокується при концентрації $\alpha$-аманітину близько $10^{-8}$ моль $л^{-1}$. Саме вплив на РНК-полімеразу і визначає токсичний есрект аматоксинів. Слід зауважити, що ДНК-залежна РНК-полімераза III інгібується тільки високою концентрацією аманітотоксинів ( $\alpha$-аманітином у концентрації $10^{-6}-10^{-7}$ моль-л $\left.{ }^{-1}\right)$, а РНК-полімераза I не чутлива до цих отрут. У результаті дії аматоксинів підвищується проникність мембран, блокується синтез мітохондрі- 
альних ДНК та білка в клітині, що порушує функціонування електронно-транспортної системи та викликає енергетичний голод. Це призводить до повної дезінтеграції синтетичних процесів у клітині (насамперед у гепатоцитах) та її загибелі [5]. Після споживання Amanita phalloides аматоксини часто індукують масивний некроз клітин печінки з високим рівнем смертності [6].

Прогресування патологічного процесу в печінці та зниження компенсаторних можливостей спричиняють ендотоксикоз, пов'язаний з порушенням показників гомеостазу і накопиченням в організмі токсичних речовин ендогенного походження [25].

$€$ й інші механізми токсичності $\alpha$-аманітину, які включають утворення активних форм кисню, що призводять до ушкодження, пов'язаного 3 окиснювальним стресом. Генерування активних форм кисню може також індукуватися підвищенням активності супероксиддисмутази й інгібуванням активності каталази. Пероксидне окиснення ліпідів може сприяти виникненню масивного некрозу і тяжкої гепатотоксичності [26]. Аматоксини можуть діяти синергічно з фактором некрозу пухлини, викликаючи апоптоз, хоча основні механізми ще не відомі. Індукований аматоксинами апоптоз також може бути зумовлений транслокацією р53 в мітохондрії, що спричиняє зміни проникності мембран мітохондрій через утворення комплексів із захисними білками (Bcl-xL та Bcl-2). Ці зміни призводять до вивільнення цитохрому с у цитозоль та активації внутрішнього шляху апоптозу [27].
Нефротоксичність після отруєння Amanita phalloides також $€$ частою. У пацієнтів може розвинутися гострий канальцевий некроз із нирковою недостатністю, що може бути наслідком прямого ушкодження нирок у результаті дії аматоксинів [28-30].

Віротоксини - це моноциклічні пептиди, представлені щонайменше п'ятьма різними сполуками: алавіроїдином, віроїзином, дезоксовіроїзином, віроїдином та дезоксовіроїдином (рис. 3 , табл. 3) [13]. Будова і біологічна активність віротоксинів подібні до таких у фалотоксинів, це дозволяє припустити, що віротоксини біосинтетично походять із фралотоксинів або мають спільні шляхи попередника. Як і фралотоксини, віротоксини не вважають суттєвими токсичними чинниками після орального впливу. Вони на молекулярному рівні, як і фалотоксини, взаємодіють з актином, стабілізуючи зв'язки між мономерами актину та запобігаючи деполімеризації мікрофріламентів. Однак ультрафріолетові спектри взаємодії між актином і віротоксинами відрізняються від спектра актин-сралотоксинів, що свідчить про іншу молекулярну взаємодію. Віротоксини мають більш гнучку структуру порівняно з фалотоксинами, а наявність двох додаткових гідроксильних груп може забезпечити різну реакційну здатність. Основною токсикологічною особливістю $€$ геморагічний некроз печінки, спричинений взаємодією віротоксинів із зовнішньою поверхнею гепатоцита через невідомі механізми [8, 31].

Різноманітність токсинів [2], виявлених у блідій поганці, разом із механізмами їх дії показано в таблиці 4.

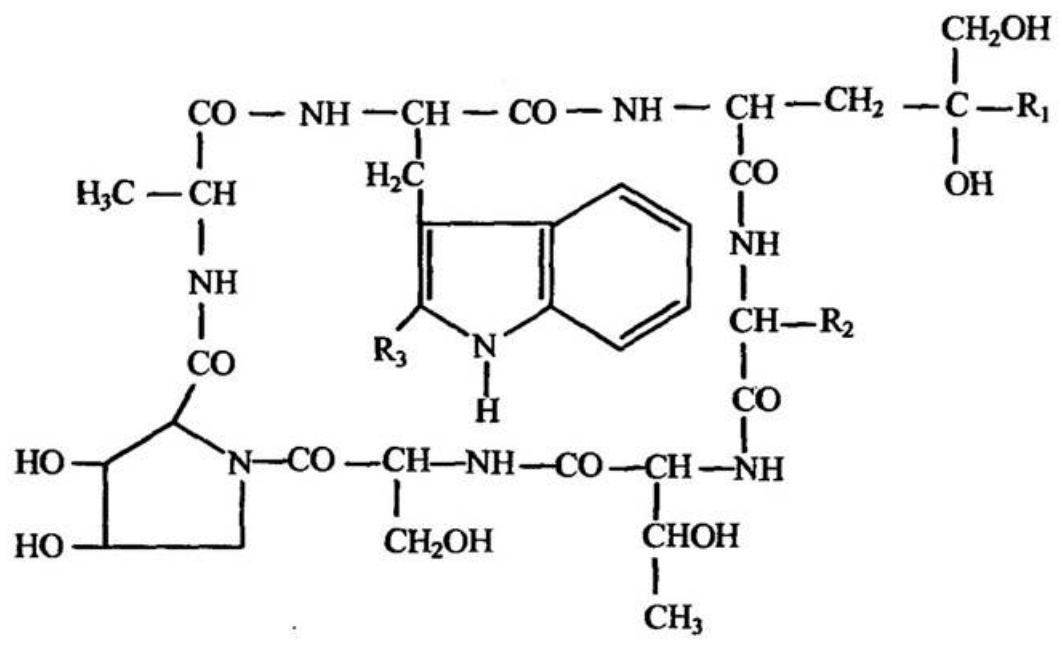

Рис. 3. Хімічна структура віротоксинів.

Таблиця 3 - Структура бічних ланцюгів віротоксинів 
Таблиця 4 - Токсикологічний профіль Amanita phalloides

\begin{tabular}{|c|c|c|c|c|}
\hline Тип токсину & $\begin{array}{l}\text { Хімічна } \\
\text { структура }\end{array}$ & $\begin{array}{l}\text { Орган- } \\
\text { мішень }\end{array}$ & Механізм дії & Подібні токсини \\
\hline Аматоксин & $\begin{array}{l}\text { Циклічний } \\
\text { гептапептид }\end{array}$ & $\begin{array}{l}\text { Печінка } \\
\text { та нирки }\end{array}$ & $\begin{array}{c}\text { Інгібування ДНК-залежної } \\
\text { РНК-полімерази II }\end{array}$ & $\begin{array}{c}\alpha \text {-аманітин, } \\
\beta \text {-аманітин }\end{array}$ \\
\hline Фалотоксин & $\begin{array}{l}\text { Циклічний } \\
\text { гептапептид }\end{array}$ & $\begin{array}{l}\text { Печінка } \\
\text { та нирки }\end{array}$ & Реакція з актином у печінці & Віротоксин \\
\hline Віротоксин & $\begin{array}{l}\text { Моноциклічний } \\
\text { гептапептид } \\
\text { (містить D-серин) }\end{array}$ & $\begin{array}{l}\text { Печінка } \\
\text { та нирки }\end{array}$ & $\begin{array}{c}\text { Порушує гомеостаз } \mathrm{Ca}^{2+} \\
\text { i реагує з актином }\end{array}$ & $\begin{array}{c}\text { Алавіроїдин, віроїзин, } \\
\text { дезоксовіроїзин, } \\
\text { віроїдин, } \\
\text { аладезоксовіроїдин } \\
\text { та оралотоксин }\end{array}$ \\
\hline Аманінамід & $\begin{array}{c}\text { Біциклічний } \\
\text { пептид та аналог } \\
\text { а-аманітину }\end{array}$ & Печінка & Інгібування РНК-полімерази II & Аматоксин \\
\hline а-аманітин & $\begin{array}{l}\text { Біциклічний } \\
\text { пептид }\end{array}$ & Печінка & Інгібування РНК-полімерази II & Аматоксин \\
\hline$\beta$-аманітин & $\begin{array}{l}\text { Біциклічний } \\
\text { пептид }\end{array}$ & Печінка & Інгібування РНК-полімерази III & Аматоксин \\
\hline Віроїзин & Циклопептид & Печінка & Реакція з актином у печінці & Віротоксин \\
\hline Віроїдин & Циклопептид & Печінка & Реакція з актином у печінці & Віротоксин \\
\hline Алавіроїдин & Циклопептид & Печінка & Реакція з актином у печінці & Віротоксин \\
\hline Дезоксовіроїзин & Циклопептид & Печінка & Реакція з актином у печінці & Віротоксин \\
\hline Аладезоксовіроїдин & Циклопептид & Печінка & Реакція з актином у печінці & Віротоксин \\
\hline Фалоїдин & Циклопептид & Печінка & Реакція з актином у печінці & Фалотоксин \\
\hline Фалацидин & Циклопептид & Печінка & Інгібування РНК-полімерази & Фалотоксин \\
\hline Токсовірин & Циклопептид & Печінка & $\begin{array}{c}\text { Високотоксичний щодо клітин } \\
\text { ссавців (його L-амінокислотна } \\
\text { оксидазна активність індукує } \\
\text { апоптоз у ракових клітинах) }\end{array}$ & Токсофралін і лектин \\
\hline
\end{tabular}

Аналіз літературних джерел обґрунтовує актуальність дослідження, оскільки лише правильне розуміння механізмів токсичності й пато- генезу отруєнь блідою поганкою здатне вивести клініциста на правильний шлях вибору варіанта інтенсивної терапії та лікування цих отруєнь.

\section{СПИСОК ЛІТЕРАТУРИ}

1. Total phenols, ascorbic acid, $\beta$-carotene and lycopene in Portuguese wild edible mushrooms and their antioxidant activities / L. Barros, M. Ferreira, B. Queirós [at al.] // Food Chemistry. - 2007. -103 (2). - P. 413-419. DOI: 10.1016/j.foodchem.2006.07.038

2. Toxicological profile of Amanita virosa -A narrative review / M. Tavassoli, A. Afshari, A. L. Arsene [at al.] // Toxicol. Rep. -2019. -9 (6). - P. 143-150. DOI: 10.1016/j. toxrep.2019.01.002.

3. Kumari D. Nutritional composition and antioxidant activities of 18 different wild Cantharellus mushrooms of Northwestern Himalayas / D. Kumari, M. S. Reddy, R. C. Upadhyay // Food Science and Technology International. - 17 (6). - P. 557-567. DOI:10.1177/ 1082013211427620.

4. Mushrooms: a potential natural source of antiinflammatory compounds for medical applications I E. A. Elsayed, H. El Enshasy, Wadaan [et al.] // Mediators Inflamm. - 2014. - 2014. DOI: 10.1155/2014/805841.
5. Недашківський С. М. Отруєння грибами: діагностика, патофрізіологія, клінічні прояви та невідкладна допомога. Сучасні підходи / С. М. Недашківський // Медицина невідкладних станів. - 2014. - № 2 (57). C. 95-101.

6. Amanita phalloides poisoning: reassessment of prognostic factors and indications for emergency liver transplantation / L. Escudié, C. Francoz, J. P. Vinel [et al] // J. Hepatol. - 2007. - 46 (3). - P. 466-473. DOI: 10.1016/j. jhep.2006.10.013.

7. Bonnet M. S. The toxicology of Amanita phalloides / M. S. Bonnet, P. W. Basson // Homeopathy. - 2002. 91 (4). - P. 249-254. DOI: 10.1054/homp.2002.0056.

8. Amanita phalloides poisoning: Mechanisms of toxicity and treatment / J. Garcia, V. M. Costa, A. Carvalho [et al.] // Food Chem. Toxicol. - 2015. - 12. - No. 86. P. 41-55.

9. Антонюк В. О. Вивчення вуглеводної специфрічності гемолітичного лектину блідої поганки (Amanita 
phalloides (Vaill. Fr.) Secr) / В. О. Антонюк // Біополімери і клітина. - 2005. - 21, № 4. - С. 319-325.

10. Zatrucia muchomorem sromotnikowym (Amanita phalloides) [Poisonings with Amanita phalloides] I T. Ferenc, B. Lukasiewicz, J. Ciećwierz [et al.] // Med. Pr. - 2009. - 60 (5). - P. 415-426.

11. Deng Y. Mushroom poisoning in children: A fiveyear review / Y. Deng, L. Qiu // Iran J. Pediatr. - 29 (1). e65262. DOI: 10.5812/ijp.65262.

12. Wieland T. Molecular pathology of the Amanita peptides. In: Peptides of Poisonous Amanita Mushrooms / T. Wieland // Springer Series in Molecular Biology. 1986. - Springer, Berlin, Heidelberg. DOI: 10.1007/9783-642-71295-1_8.

13. Vetter $\mathrm{J}$. Death cap poisoning and the animals. Literature review / J. Vetter, Sz. Vetter // Magyar Allatorvosok Lapja. - 2014. - 136 (12). - P. 750-758. -Access mode : https://www.researchgate.net/publication/ 288240271_Death_cap_poisoning_and_the_animals_ Literature review.

14. Amanitin and phallotoxin concentration in Amanita phalloides var. alba mushroom / E. Kaya, I. Yilmaz, Z. A. Sinirlioglu [et al.] // Toxicon: Official Journal of the International Society on Toxinology. - 2013. - 76. P. 225-233. Access mode : https://doi.org/10.1016/j. toxicon.2013.10.008.

15. Poisoning associated with the use of mushrooms: A review of the global pattern and main characteristics / S. Govorushko, R. Rezaee, J. Dumanov [et al.] // Food and chemical toxicology: an international journal published for the British Industrial Biological Research Association. - 2019. - 128. P. 267-279. DOI: 10.1016/j. fct.2019.04.016.

16. Shier W. T. Handbook of Toxinology / W. T. Shier // CRC Press. - 2020. - P. 872. Access mode : https:// books.google.com.ua/books?id=ogn-DwAAQBAJ\&hl=uk

17. Lutsik-Kordovsky M. D. Analysis of cytotoxicity of lectin and non-lectin proteins fromAmanita mushrooms. I M. D. Lutsik-Kordovsky, T. V. Stasyk, R. S. Stoika // Experimental Oncology. - 2001. - 23 (1). - P. 43-45. https://exp-oncology.com.ua/wp/wp-content/uploads/ magazine/157.pdf?upload=

18. Nayak A. P. Fungal hemolysins / A. P. Nayak, B. J. Green, D. H. Beezhold, Medical Mycology. - 2013. 51 (1). - P. 1-16. DOI: 10.3109/13693786.2012.698025.

19. Mushroom poisoning in the northeast of Iran; a retrospective 6-year epidemiologic study / B. Dadpour, S. Tajoddini, M. Rajabi [at al] // Emerg. (Tehran). - 2017. 5. - e23. Epub 2017 Jan 10. PMID: 28286830; PMCID: PMC5325892.

20. Himmelmann A. Lethal ingestion of stored Amanita phalloides mushrooms. / A. Himmelmann, G. Mang,
S. Schnorf-Huber // Swiss Med. Wkly. - 2001. - 131 (4142). - P. 616-617. PMID: 11820073.

21. Karlson-Stiber C. Cytotoxic fungi-an overview / C. Karlson-Stiber, H. Persson // Toxicon. - 2003. - 42. P. 339-349. DOI: 10.1016/s0041-0101(03)00238-1

22. Cyclopeptide toxins of lethal amanitas: compositions, distribution and phylogenetic implication / S. Tang, Q. Zhou, Z. He [et al] // Toxicon. -2016. -120. - P. 78-88. DOI: 10.1016/j.toxicon.2016.07.018 0041-0101.

23. Кузьмак І. П. Динаміка показників ендогенної інтоксикації у щурів різного віку за умов гострого отруєння токсинами блідої поганки [Електронний ресурс]/І. П. Кузьмак, І. М. Кліщ, О. З. Яремчук // Наук. вісн. Ужгород. ун-ту. Серія "Біологія". - 2012. Вип. 33. - С. 154-157. - Режим доступу : http://nbuv. gov.ua/UJRN/Nvuu_2012_33_24.

24. Molecular characterization and inhibition of Amanitin uptake into human hepatocytes / K. Letschert, H. Faulstich, D. Keller [at al] // Toxicological Sciences. 91 (1). - P. 140-149. DOI: 10.1093/toxsci/kfj141.

25. Кузьмак І. П. Деякі показники білкового обміну в щурів, отруєних блідою поганкою / І. П. Кузьмак // Мед. та клініч. хімія. - 2018. - 20, № 4 (77). - С. 130135.

26. Zheleva A. Phenoxyl radicals formation might contribute to severe toxicity of mushrooms toxin alphaamanitin- an electron paramagnetic resonance study / A. Zheleva//TJS. -2013.-11.-P. 33-38. -Access mode : http://www.uni-sz.bg/tsj/vol11N1_2013/A.Jeleva.pdf.

27. Transcriptional blockade induces p53-dependent apoptosis associated with translocation of p53 to mitochondria / Y. Arima, M. Nitta, S. Kuninaka [et al.] // J. Biol. Chem. - 2005. - 280 (19). - P. 19166-19176. DOI: $10.1074 / \mathrm{jbc}$.

28. West P. L. Amanita smithiana mushroom ingestion: a case of delayed renal failure and literature review / P. L. West, J. Lindgren, B. Z. Horowitz // Journal of Medical Toxicology. - 2009. - 5 (1). - P. 32-38. DOI: 10.1007/ BF03160979.

29. Acute Renal Failure Caused by Mushroom Poisoning / Wei-Shun Yang, Chih-Hao Lin, Jenq-Wen Huang [et al] // Journal of the Formosan Medical Association. -2006. -105(3).-P. 263-267. DOI: 10.1016/ S0929-6646(09)60317-X.

30. Diaz J. H. Amatoxin-containing mushroom poisonings: Species, toxidromes, treatments, and outcomes / J. H. Diaz // Wilderness Environ. Med. - 2018. 29 (1). - P. 111-118. DOI: 10.1016/j.wem.2017.10.002.

31. Horowitz B. Z. (2020). Amatoxin mushroom toxicity / B. Z. Horowitz, M. J. Moss. - In StatPearls. StatPearls. - Access mode : https://www.ncbi.nlm.nih. gov/books/NBK431052/?report=reader\#_NBK431052_ pubdet

\section{REFERENCES}

1. Barros, L., Ferreira, M., Queirós, B., Ferreira, F.R., \& Baptista, P. (2007). Total phenols, ascorbic acid, $\beta$-carotene and lycopene in Portuguese wild edible mushrooms and their antioxidant activities. Food Chemistry, 103 (2), 413-419. DOI: 10.1016/j.foodchem. 2006.07.038
2. Tavassoli, M., Afshari, A., Arsene, A.L., Mégarbane, B., Dumanov, J., \& Paoliello, et al. (2019). Toxicological profile of Amanita virosa - A narrative review. Toxicol. Rep., 9 (6), 143-150. DOI: 10.1016/j.toxrep.2019.01.002.

3. Kumari, D., Reddy, M.S., \& Upadhyay, R.C. (2011). Nutritional composition and antioxidant activities of 18 
different wild Cantharellus mushrooms of Northwestern Himalayas. Food Science and Technology International, 17 (6), 557-567. DOI: 10.1177/ 1082013211427620ю

4. Elsayed, E.A., El Enshasy, H., Wadaan, M.A., \& Aziz, R. (2014). Mushrooms: a potential natural source of anti-inflammatory compounds for medical applications. Mediators Inflamm., Mediators of Inflammation, 2014. DOI: $10.1155 / 2014 / 805841$.

5. Nedashkivskyi, S.M. (2014). Otruiennia hrybamy: diahnostyka, patofiziolohiia, klinichni proiavy ta nevidkladna dopomoha. Suchasni pidkhody [Mushroom poisoning: diagnosis, pathophysiology, clinical manifestations and emergency care. Modern approaches] Medytsyna nevidkladnykh staniv - Medicine of Emergencies, 2 (57), 95-101 [in Ukrainian].

6. Escudié, L., Francoz, C., Vinel, J.P., Moucari, R., Cournot, M., Paradis, V., et al. (2007). Amanita phalloides poisoning: reassessment of prognostic factors and indications for emergency liver transplantation. J. Hepatol., 46 (3), 466-473. DOI: 10.1016/j.jhep.2006.10.013.

7. Bonnet, S., \& Basson, P.W. (2002). The toxicology of Amanita phalloides, Homeopathy, 91 (4), 249-254, DOI: 10.1054/homp.2002.0056.

8. Garcia, J., Costa, V.M., Carvalho, A., Baptista, P., de Pinho, P.G., de Lourdes Bastos, M., \& Carvalho, F. (2015). Amanita phalloides poisoning: Mechanisms of toxicity and treatment. Food Chem. Toxicol., 86, 41-55. DOI: 10.1016/j.fct.2015.09.008.

9. Antoniuk, V.O. (2005). Vyvchennia vuhlevodnoi spetsyfichnosti hemolitychnoho lektynu blidoi pohanky (Amanita phalloides (Vaill. Fr.) Secr) [Study on carbohydrate specificity of hemolytic lectin from death-cap mushroom (Amanita phalloides (Vaill. Fr.) Secr)]. Biopolimery i klityna - Cell Biology Biopolym. Cell, 21 (4), 319-325. DOI: 10.7124/bc.0006F8.

10. Ferenc, T, Lukasiewicz, B., Ciećwierz, J., \& Kowalczyk, E. (2009). Zatrucia muchomorem sromotnikowym (Amanita phalloides). Med. Pr., 60 (5), 415-426.

11. Deng, Y., \& Qiu, L. (2019). Mushroom poisoning in children: A five-year review. Iran J. Pediatr., 29 (1), e65262. DOI: 10.5812/ijp.65262.

12. Wieland T. (1986) Molecular pathology of the Amanita peptides. In: Peptides of Poisonous Amanita Mushrooms. Springer Series in Molecular Biology. Springer, Berlin, Heidelberg. DOI: 10.1007/978-3-64271295-1_8.

13. Vetter, J., \& Vetter, Sz. (2014). Death cap poisoning and the animals. Literature review. Magyar Allatorvosok Lapja, 136 (12), 750-758. Retrieved from: https:// www.researchgate.net/publication/288240271_Death cap_poisoning_and_the_animals_Literature_review.

14. Kaya, E., Yilmaz, I., Sinirlioglu, Z.A., Karahan, S., Bayram, R., Yaykasli, K. O., Colakoglu, S., Saritas, A., \& Severoglu, Z. (2013). Amanitin and phallotoxin concentration in Amanita phalloides var. alba mushroom. Toxicon: Official Journal of the International Society on Toxinology, 76, 225-233. Retrieved from: https://doi.org/10.1016/ j.toxicon.2013.10.008.

15. Govorushko, S., Rezaee, R., Dumanov, J., \& Tsatsakis, A. (2019). Poisoning associated with the use of mushrooms: A review of the global pattern and main characteristics. Food and Chemical Toxicology: An International Journal published for the British Industrial
Biological ResearchAssociation, 128, 267-279. Retrieved from: https://doi.org/10.1016/j.fct.2019.04.016.

16. Shier, W.T. (2020). Handbook of toxinology CRC Press. Retrieved from: https://books.google.com.ua/ books?id=ogn-DwAAQBAJ\&hl=uk.

17. Lutsik-Kordovsky, M.D. Stasyk, T.V., \& Stoika, R.S. (2001). Analysis of cytotoxicity of lectin and non-lectin proteins from Amanita mushrooms. Experimental Oncology, 23 (1), 43-45. Retrieved from: https://exp-oncology.com.ua/ wp/wp-content/uploads/magazine/157.pdf?upload=

18. Nayak, A.P., Green, B.J., \& Beezhold, D.H. (2013). Fungal hemolysins. Medical Mycology, 51 (1), 1-16. DOI: 10.3109/13693786.2012.698025.

19. Dadpour, B., Tajoddini, S., Rajabi, M., \& Afshari, R. (2017). Mushroom poisoning in the northeast of Iran; a retrospective 6-year epidemiologic study. Emerg. (Tehran), 5 (1), e23. Epub 2017 Jan 10. PMID: 28286830; PMCID: PMC5325892.

20. Himmelmann, A., Mang, G., \& Schnorf-Huber, S. (2001). Lethal ingestion of stored Amanita phalloides mushrooms. Swiss Medical Weekly, 131 (41-42), 616617.

21. Karlson-Stiber, C., \& Persson, H. (2003). Cytotoxic fungi-an overview. Toxicon: Official Journal of the International Society on Toxinology, 42(4), 339-349. DOI: 10.1016/s0041-0101(03)00238-1.

22. Tang, S., Zhou, Q., He, Z., Luo, T, Zhang, P., \& Cai, Q. et al (2016). Cyclopeptide toxins of lethal amanitas: compositions, distribution and phylogenetic implication Toxicon, 120, 78-88. DOI: 10.1016/j.toxicon.2016. $07.0180041-0101$.

23. Kuzmak, I.P., Klishch, I.M., \& Yaremchuk, O.Z. (2012). Dynamika pokaznykiv endohennoi intoksykatsii u shchuriv riznoho viku za umov hostroho otruiennia toksynamy blidoi pohanky [Dynamics of endogenous intoxication in rats of different ages under conditions of acute poisoning by toxins of the pale toadstool]. Naukovyi visnyk Uzhhorodskoho universytetu. Seriia: Biolohiia Scientific Bulletin of Uzhhorod University. Series: Biology, 33, 154-157. Retrieved from: http://nbuv.gov.ua/UJRN/ Nvuu_2012_33_24.

24. Letschert, K., Faulstich, H., Keller, D., \& Keppler, D. (2006). Molecular characterization and inhibition of Amanitin uptake into human hepatocytes, Toxicological Sciences, 91 (1), 140-149. DOI: 10.1093/ toxsci/kfj141.

25. Kuzmak, I.P. (2018). Deiaki pokaznyky bilkovoho obminu v shchuriv, otruienykh blidoiu pohankoiu [Some indicators of protein metabolism in rats poisoned by Amanita phalloides]. Medychna ta klinichna khimiia Medical and Clinical Chemistry, 20 (4). DOI: 10.11603/ mcch.2410-681X.2018.v0.i4.9825.

26. Zheleva, A. (2013). Phenoxyl radicals formation might contribute to severe toxicity of mushrooms toxin alpha-amanitin- an electron paramagnetic resonance study. TJS, 11, 33-38. Retrieved from: http://www.uni-sz. bg/tsj/vol11N1_2013/A.Jeleva.pdf.

27. Arima, Y., Nitta, M., Kuninaka, S., Zhang, D., Fujiwara, T., Taya, Y., Nakao, M., \& Saya, H. (2005). Transcriptional blockade induces p53-dependent apoptosis associated with translocation of p53 to mitochondria. J. Biol. Chem., 280 (19), 19166-19176. DOI: 10.1074/ jbc.M410691200. 
28. West, P.L., Lindgren, J., \& Horowitz, B.Z.. (2009). Amanita smithiana mushroom ingestion: a case of delayed renal failure and literature review. Journal of Medical Toxicology, 5 (1), 32-38. DOI: 10.1007/BF03160979.

29. Wei-Shun Yang, Chih-Hao Lin, Jenq-Wen Huang, \& Cheng-Chung Fang. (2006). Acute renal failure caused by mushroom poisoning. Journal of the Formosan Medical Association, 105 (3), 263-267. DOI: 10.1016/S09296646(09)60317-X.
30. Diaz, J.H. (2018). Amatoxin-containing mushroom poisonings: Species, toxidromes, treatments, and outcomes. Wilderness Environ. Med., 29 (1), 111-118. DOI: 10.1016/j.wem.2017.10.002.

31. Horowitz, B.Z., \& Moss, M.J. (2020). Amatoxin mushroom toxicity. In StatPearls. StatPearls Publishing. https://www.ncbi.nlm.nih.gov/books/NBK431052/?report=reader\#_NBK431052_pubdet_

\section{И. П. Кузьмак \\ ТЕРНОПОЛЬСКИЙ НАЦИОНАЛЬНЫЙ МЕДИЦИНСКИЙ УНИВЕРСИТЕТ ИМЕНИ И. Я. ГОРБАЧЕВСКОГО \\ ОТРАВЛЕНИЕ БЛЕДНОЙ ПОГАНКОЙ: МЕХАНИЗМ ТОКСИЧНОСТИ И ПАТОГЕНЕЗ ПОРАЖЕНИЯ (ОБЗОР ЛИТЕРАТУРЫ)}

МОЗ УКРАИНЫ

\section{Резюме}

Вступление. Бледная поганка (Amanita phalloides) является одним из самых опасных ядовитых грибов. Ее токсины относятся к сильным ядам, которые проявляют гепатонефротропное действие, а учитывая отсутствие специфрических антидотов к ним, лечение отравлений этим грибом остается важной проблемой. Токсины бледной поганки разделяют на три группы: фралотоксины, поражающие эндоплазматическую сеть, аматоксины, которые действуют медленнее, но почти в 20 раз более ядовитые, чем первые, и виротоксины. Аматоксины являются основными токсинами Amanita phalloides и одними из самых опасных природных токсинов, вызывающих печеночную, почечную, в челом полиорганную, недостаточность вследствие угнетения синтеза протеина на уровне транскрипции внутри энтероцитов, гепатоцитов и проксимальных канальцевых клеток почек. После потребления Amanita phalloides aмaтоксины часто индуцируют массивный некроз клеток печени с высоким уровнем смертности, который достигает иногда $90 \%$.

Существенное значение в патогенезе аманита-фраллоидинового повреждения предоставляют нарушению обмена протеинов вследствие угнетения РНК-полимеразы II клеток, прямому ингибирующему действию на активность уже синтезированных энзимов и косвенному влиянию на энзимные системы через субстраты.

Другим механизмом токсичности а-аманитина является образование активных фрорм кислорода, что приводит к повреждению, связанному с окислительным стрессом. Перекисное окисление липидов может способствовать возникновению массивного некроза и тяжелой гепатотоксичности.

В этой работе приведен подробный обзор литературы об отравлении основными токсинами бледной поганки. В статье обсуждаются вопросы относительно биохимии аматоксинов, фралотоксинов и других токсинов бледной поганки, механизмов токсичности, патогенеза отравления этим грибом.

В данной работе использованы общенаучные методы исследования, включающие экспертно-аналитический обзор научных источников, анализ и синтез литературных данных.

Цель исследования - проанализировать современные литературные источники о биохимии токсинов бледной поганки, механизмах токсичности, патогенезе отравления этим грибом.

Вывод. Анализ литературных источников обосновывает актуальность исследования механизмов токсичности и патогенеза поражения токсинами бледной поганки с целью выявления метаболических нарушений, что необходимо для прогнозирования тяжести течения патологического процесса, поиска и разработки методов лечения аматоксин-сраллоидиновых отравлений.

КЛЮЧЕВЫЕ СЛОВА: бледная поганка; отравление грибами; гепатотоксичность; аматоксины; фалотоксины; виротоксины. 


\section{AMANITA PHALLOIDES POISONING: MECHANISM OF TOXICITY AND PATHOGENESIS OF THE INJURY (LITERATURE REVIEW)}

\section{Summary}

Introduction. Amanita phalloides is one of the most dangerous poisonous fungi. Amanita phalloides toxins are strong poisons that have a hepatonephrotropic effect, and due to the lack of specific antidotes to them, the treatment of poisoning by this fungus remains an important problem. Amanita phalloides toxins are divided into three groups: phallotoxins, which affect the endoplasmic reticulum, and amatoxins, which act more slowly, but are almost 20 times more toxic than the former and virotoxins. Amatoxins are the major toxins of Amanita phalloides and one of the most dangerous natural toxins that cause liver, kidney, and, in general, multiorgan failure due to inhibition of protein synthesis at the level of transcription within enterocytes, hepatocytes, and proximal tubular cells of the kidney. After taking Amanita phalloides, amatoxin often induces massive necrosis of liver cells with a high mortality rate, which sometimes reaches up to $90 \%$.

Significant importance in the pathogenesis of ammanite-phalloidin damage is given to disorders of protein metabolism due to inhibition of RNA polymerase II cells, direct inhibitory effect on the activity of already synthesized enzymes and indirect effects on enzyme systems through substrates.

Another mechanism of $\alpha$-amanitin toxicity is the formation of reactive oxygen species, which leads to damage associated with oxidative stress. Lipid peroxidation can contribute to massive necrosis and severe hepatotoxicity.

This paper presents a detailed overview of the poisoning of the main toxins of the Amanita phalloides. The article discusses the biochemistry of amatoxin, phalloidin and other toxins of Amanita, mechanisms of toxicity, pathogenesis of poisoning by Amanita phalloides.

The paper uses general scientific research methods, including expert-analytical review of scientific sources, analysis and synthesis of literature data.

The aim of the study - to analyze current literature sources on the biochemistry of Amanita phalloides toxins, mechanisms of toxicity, pathogenesis of Amanita phalloides poisoning.

Conclusions. The analysis of literature sources substantiates the relevance of the study of the mechanisms of toxicity and pathogenesis of toxins of the Amanita phalloides in order to identify metabolic disorders, which is necessary to predict the severity of the pathological process, search and development of treatments for amatoxinphaloidin poisoning.

KEY WORDS: Amanita phalloides; mushroom poisoning; hepatotoxicity; amatoxins; phallotoxins; virotoxins.

Отримано 12.11.20

Адреса для листування: І. П. Кузьмак, Тернопільський національний медичний університет імені І. Я. Горбачевського мОз України, майдан Волі, 1, Тернопіль, 46001, Україна, е-mail: kuzmak@tdmu.edu.ua. 